\title{
Signal filtering method of the fast-varying diesel exhaust gas temperature
}

The paper presents the problem of the impact of external distortions originating on laboratory test stands on the results of measurements of fast-varying diesel exhaust gas temperature. It has been stressed how significant the aspect of the test stand adaptation is during an experiment to ensure the smallest possible impact. This paper, however, focuses on the methods of mathematical processing of a signal recorded during experimental research of a real object. The most significant parameter requiring filtering is the fast-varying exhaust gas temperature in the engine exhaust channel. Methods of mathematical processing adequate to this type of distorted signal have been presented, particularly those that can be used in the Matlab environment and consisting in averaging of the obtained curves of temperature changes. The results of the application of these methods have also been presented on actual curves recorded during laboratory tests and their evaluation has been made.

Keywords: diesel engine, exhaust temperature, parametrical diagnostics, signal mathematical processing

\section{Introduction}

Diesel exhaust gas parameter-based diagnostics is an important problem of contemporary engineering. The influence of external factors on the obtained signal is significant and engineers should aim at developing efficient methods to minimize this distortion. Aiming at a development of a method of diagnosis of the components of this type of objects based on the measurements of fast-varying exhaust gas temperature, a tool should be developed for mathematical processing and interpretation of the signals obtained during research. The performed analysis of the results of experimental investigations performed on piston engines thus far $[12,15,1]$, during which fast varying pressures and temperatures of exhaust were recorded, has shown an existence of many important metrological issues. The most significant is the inertia of the thermocouples and the influence of the external factors (from the test stand and the immediate surroundings) on the obtained results. Therefore, this influence is to be minimized by selecting appropriate measurement techniques and measurement equipment [14]. At the same time, algorithms are applied that allow determining of the actual curve of the fast-varying exhaust temperature that is free from the said distortions. This, however, requires a selection of an appropriate method of mathematical processing of the signal obtained under laboratory conditions. There are many methods of mathematical processing of signals distorted with external factors. The determination of the right method allows a proper interpretation of the obtained results, which, in the long run, enables a determination of the diagnostic method that would allow analyses of the design structure of diesel engines based on fast-varying exhaust temperatures.

The aim of this paper is to present the most appropriate (in the author's judgment) methods of mathematical processing of fast-varying gas temperature as a diagnostic parameter. The presented methods are part of an algorithm aiming at a description of the process of diagnosis of structural components of diesel piston engines based on the exhaust gas temperature in the exhaust system. While the methods of fast varying temperature signal filtering are known, the procedure of diagnosing of piston machines worthiness based on these parameters is innovative. Thus far, the most widely applied diagnostic parameter of piston machines in laboratory experiments and investigations on real objects was pressure. Diagnostic investigations based on fast-varying exhaust temperature was performed by Rutkowski in 1976, yet this method has not been fully developed [8]. The components of the method under development are known but the algorithm itself, whose one of the elements was presented, has not been described in literature. The presented methods of signal filtering are often described in theory. In this paper, the application of digital filters for mathematical processing of the laboratory test results has been shown and their usefulness in the process of parametrical diagnosis of piston machines has been evaluated.

\section{Results obtained on a laboratory test stand from a single cylinder diesel engine}

Empirical research was performed on a laboratory test stand on a Farymann D10 four-stroke single cylinder diesel engine (Fig. 1, 2a,b). The basic engine specifications are as follows:

- rated power $5.9 \mathrm{~kW}$,

- engine speed $1500 \mathrm{~min}^{-1}$,

- torque $38 \mathrm{~N} \cdot \mathrm{m}$,

- cylinder bore $90 \mathrm{~mm}$,

- cylinder stroke $120 \mathrm{~mm}$,

- compression ratio 22:1,

- displacement $765 \mathrm{~cm}^{3}$.

During the research, the following indictors were recorded:

- exhaust gas temperature recorded with a type K thermocouple in a ceramic sheath,

- exhaust gas temperature recorded with a type K thermocouple additionally cooled with a water coat,

- exhaust gas pressure in the exhaust channel,

- signal of the top dead center,

- generator load current (armature),

- voltage at the terminals of the generator armature,

- exhaust valve opening signal.

Table 1 presents the measured control parameters and the measurement equipment used in the research.

For the recording of the fast-varying temperatures, the pressures and the top dead center signal, a multifunctional 
measurement and recording module (DT - 9805 by Data Translation) was used. For the storage of the recorded parameters the authors used Matlab. During the tests, a constant engine speed of $1280 \mathrm{~min}^{-1}$ was maintained. The sampling frequency was $8000 \mathrm{~Hz}$. The tests were carried out on an unloaded engine and the presented results are an average from several consecutive measurements performed under the same conditions.

The parameters of the exhaust gas recorded during a single engine work cycle of a four stroke engine were analyzed in order to compare the curves of the fast-varying temperature recorded with two thermocouples of different design and with a graphic tracing being clearer for physical interpretation. From the data presented in Fig. 3, one can observe a significant difference in the readings of the two thermocouples - the average exhaust gas temperature indicated by the water-cooled thermocouple is much lower (tens of degrees Centigrade). This requires a further analysis of the influence of the thermocouple cooling on its readings. An important advantage of the application of a water cooled thermocouple, however, are less distorted curves with more evident temperature surges, which results from the minimization of the heating of the thermocouple body from the walls of the channel, in which it is mounted.

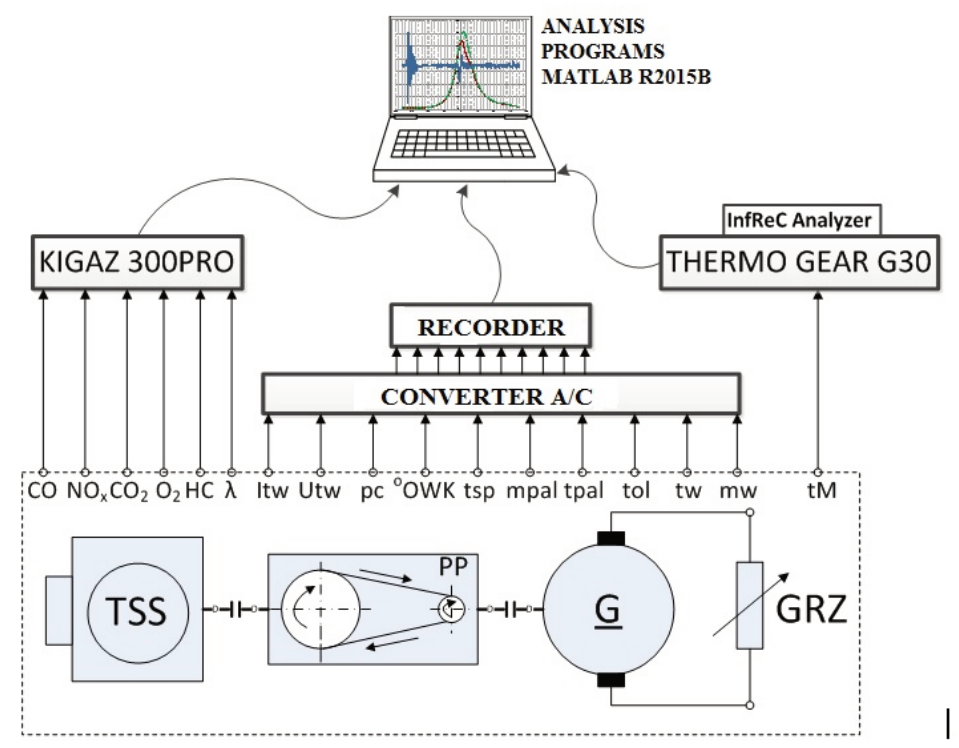

Fig. 1. Schematics of the test stand with the measurement signals recording and processing system: TSS-Farymann D10 diesel engine; PP - belt transmission; G - direct current generator; GRZ - system of heaters [9]

a)

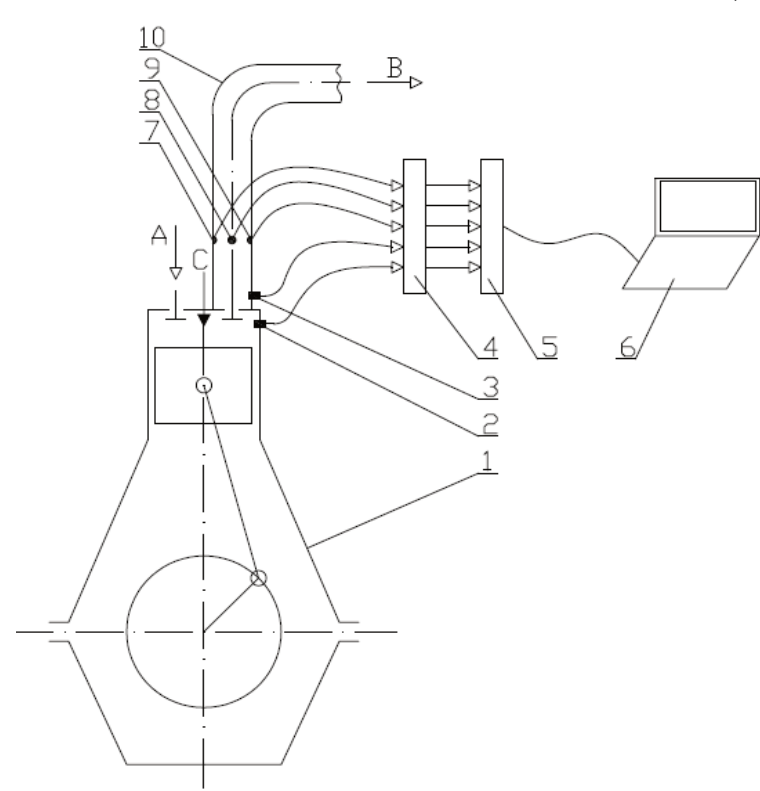

b)

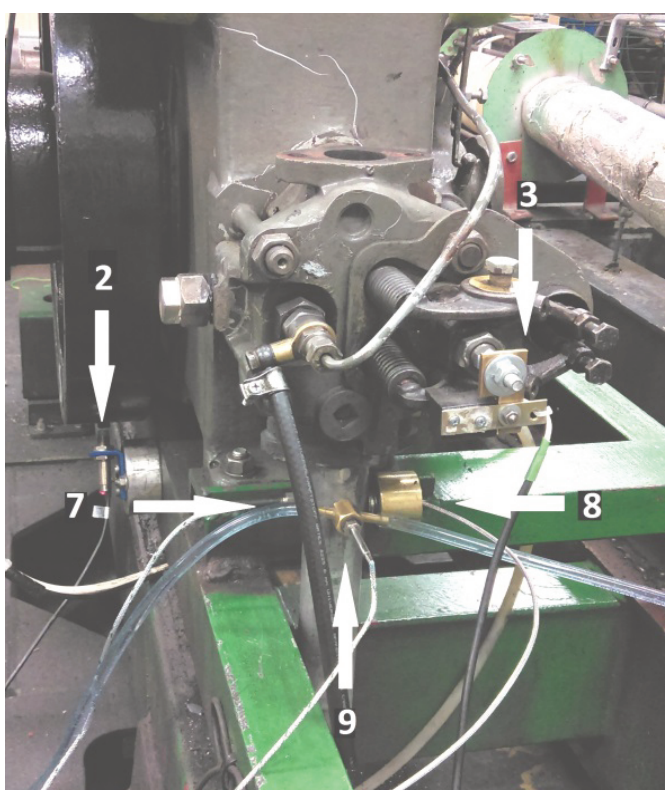

Fig. 2. a) Diagram of the laboratory test stand with the fitting spots of the sensors marked: 1 - Farymann D 10 engine, 2 - engine speed and TDC sensor, 3 - exhaust valve opening sensor, 4 - A/C converter, 5 - recorder, 6 - analysis software, 7 - thermocouple in a ceramic sheath, 8 - pressure sensor, 9 water cooled thermocouple, 10 - exhaust gas channel, A - intake air, B - exhaust gas, C - fuel line; b) view of the laboratory test stand with the fitting spots of the sensors of the recorded parameters marked: 2 - engine speed and TDC sensor, 7 - thermocouple in a ceramic sheath, 9 - water cooled thermos-couple, 3 - exhaust valve opening sensor, 8 - pressure sensor 
The exhaust valve closing (opening) signal indicated in Figs 3-6 is a hypothetical point of valve closing (opening). This is caused by the imperfection of the method of recording of this parameter (Tab. 1). The determination of this point within the engine work cycle is only for information purposes and is of no significance for the diagnostic method under development. Therefore, the values in the figures deviating from $720^{\circ} \mathrm{C}$.A. within a single work cycle of a diesel engine, result from the above. They were left unmodified due to a rather negligible informative value.

\section{The influence of the distortions on the fast-varying temperature signal}

There are many factors influencing the signal of the fast-varying exhaust temperature in the exhaust channel of a diesel engine obtained in the laboratory tests. These are mainly the internal and external distortions that come from the following sources:

- unrepeatability of the injection and combustion processes for each diesel engine work cycle,

- wear of the engine components as well as the injection system,

- immediate surroundings of the test stand (ambient air, interference of physical fields, etc.),

- measurement chain (equipment and connection) and the power grid,

- inertia of the temperature recording sensor (thermocouple).

The listed factors may generate distortions of the temperature signal making it impossible to properly interpret the obtained curve. From the analysis of the research performed thus far, it results that there is a deviation from the average exhaust temperature reaching several degrees Celsius (Fig. 3). One can also observe a difference of the variability of the temperature signal of the same exhaust flow recorded with two different thermocouples: the watercooled and the one without cooling. The heating of the thermocouple from the exhaust channel, in which it is fitted, results in much higher temperature readings compared to the water-cooled thermocouple. One can also observe a less clear and longer-to-respond temperature variability curve resulting from a greater inertia of the thermocouple without cooling.

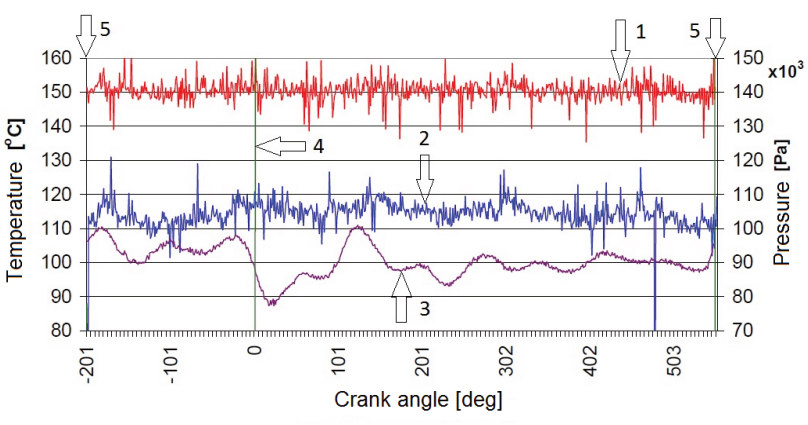

Fig. 3. Curves of the temperature changes recorded in the exhaust channel of the Farymann D10 engine with two type $\mathrm{K}$ thermocouples during a single work cycle: 1 - temperature recorded with the exposed thermocouple, 2 - temperature recorded with the water-cooled thermocouple, 3 pressure in the exhaust channel, 4 - exhaust valve closing signal, 5 exhaust valve opening signal

In order to minimize the influence of the external factors on the results of the Farymann Diesel D10 engine exhaust temperature measurements on a laboratory test stand (Fig. 2), the exhaust channel was modernized [14]. The exhaust channel was made a straight fragment and the sensor along with both thermocouples were fitted at the same distance from the exhaust valve. Despite an improvement of the technical conditions of the measurements, it is sometimes necessary to develop an appropriate method of mathematical processing of the obtained results.

\section{The proposed method of mathematical processing of the fast-varying temperature signal - filters in the Matlab environment}

Performance of research on an actual object generates a problem of receiving signals that contain distortions. The making of a measurement and obtaining a file containing measurement data is the preliminary stage of the research. For the analysis of the results, it is necessary to apply proper computer software that would allow elimination of the distortions from the obtained curves. There is generally available software such as Mathcad, Matlab, Microsoft Excel or Analysis Toolpak that allows numerical data analysis. The review of the available software has indicated that the most advantageous environment for scientific calculations is Matlab with appropriate Excel support.

Tab. 1. The parameters of the Farymann D10 single cylinder diesel engine recorded on the laboratory test stand

\begin{tabular}{|c|c|c|c|c|}
\hline Item & Parameter & Measuring device & unit & Measurement range \\
\hline 1. & Exhaust gas temperature $-\mathrm{T}_{\mathrm{sp} 1}$ & $\begin{array}{c}\text { Exposed junction type } \mathrm{K} \text { thermocouple } \\
\text { (junction diameter } 0.2 \mathrm{~mm} \text {, ceramic sheath) }\end{array}$ & ${ }^{\circ} \mathrm{C}$ & $0-1000$ \\
\hline 2. & Exhaust gas temperature $-\mathrm{T}_{\mathrm{sp} 2}$ & $\begin{array}{l}\text { Grounded type } \mathrm{K} \text { thermocouple with the } \\
\text { junction of external diameter of } 0.5 \mathrm{~mm} \text {, } \\
\text { made from inconell }\end{array}$ & ${ }^{\circ} \mathrm{C}$ & $0-1000$ \\
\hline 3. & Exhaust gas pressure in the exhaust channel $-\mathrm{p}_{\mathrm{sp}}$ & Optical pressure sensor - Optrand C12296 & V & $\begin{array}{c}0-689475.73 \mathrm{~Pa}(0-100 \mathrm{psi}) \\
\text { sensitivity } 6.01 \cdot 10^{-8} \mathrm{~V} / \mathrm{Pa} \\
(41.43 \mathrm{mV} / \mathrm{psi})\end{array}$ \\
\hline 4. & $\begin{array}{c}\text { Engine speed (angular position }{ }^{\circ} \text { C.A.) }-\mathrm{n} \\
\text { Top dead center - TDC }\end{array}$ & $\begin{array}{l}\text { Induction engine speed sensor and TDC } \\
\text { sensor }\end{array}$ & $\min ^{-1}$ & $0-3000$ \\
\hline 5. & Load Current of the generator (armature) $-\mathrm{I}_{\mathrm{tw}}$ & Electric current meter & A & $0-15$ \\
\hline 6. & Voltage at the armature terminals- $\mathrm{U}_{\mathrm{tw}}$ & Voltmeter & $\mathrm{V}$ & $0-250$ \\
\hline 7. & Exhaust valve opening signal & $\begin{array}{l}\text { Gap type opto-isolator with a comparator } \\
\text { LM393 }\end{array}$ & $\begin{array}{c}\mathrm{V} \\
\mathrm{mm}\end{array}$ & $\begin{array}{c}0-5 \\
10 \text { (gap) }\end{array}$ \\
\hline
\end{tabular}


The main task of a digital filter is the improvement of the quality of the processed signal through its smoothing while still maintaining its original shape. Upon the analysis of popular digital signal filters, the authors decided on the application of 3 filtering methods: Savitzky-Golay filtering, median filtering and envelope filtering [16].

The Savitzky-Golay filter is a digital filter applied for a group of measurement points to smooth the curves i.e. increase the signal noise ratio without significant distortion of the signal itself. This is obtained in the process of convolution by adapting subsequent subsets of neighboring data points to the low degree polynomial with the method of least squares. The method, based on established procedures, was popularized by Savitzky and Golay in 1964 [18].

The median filter is a non-linear filter whose principle of operation is selecting the median value of a sequence of values in the ascending order of data of the processed point and its surroundings. The advantage of the median filter is that all of the values that deviate from the average are omitted when new values of the measurement point are calculated. The envelope filter utilizes the signal envelope, i.e. an instantaneous value of the signal amplitude as a function of time that changes much more slowly than the signal itself.

\section{The application of the filtering methods in the mathematical processing of the laboratory test results}

The signal of fast-varying exhaust temperature obtained during laboratory tests on a laboratory test stand (Farymann Diesel D10) was subjected to mathematical processing. After the application of the 3 filtering methods (Savitzky and Golay, envelope, median) for the curves recorded by both applied thermocouples (Fig. 4 and 5), clearer readings were obtained that were free from the noise resulting from external factors. One can see, however, a significant delay of the exhaust temperature recorded by the thermocouple against the records of the pressure pulses. The power grid buzz was eliminated as the entire measurement chain was powered from a battery.

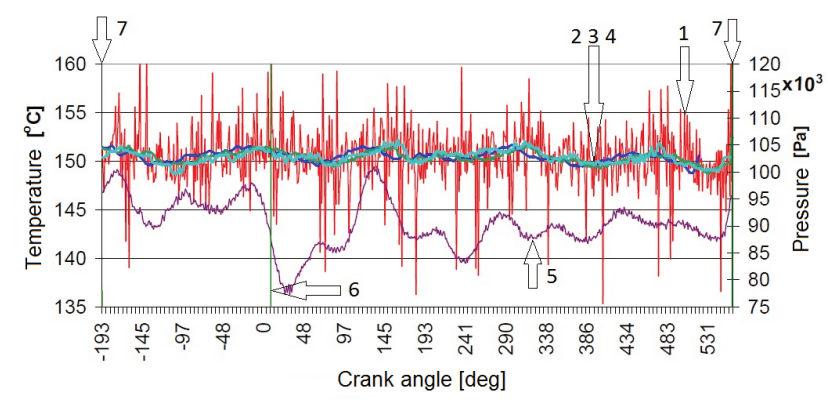

Fig. 4. Temperature change curves recorded in the exhaust channel of the Farymann D10 diesel engine with a type K thermocouple (exposed junction, ceramic sheath) during one of the work cycles filtered in Matlab: 1 temperature recorded with a thermocouple with exposed junction, $2-$ temperature curve after the Savitzki and Golay filter, 3 - temperature curve after the median filter, 4 - temperature curve after the envelope filter 5 - pressure in the exhaust channel, 6 - exhaust valve closing signal, 7 exhaust valve opening signal

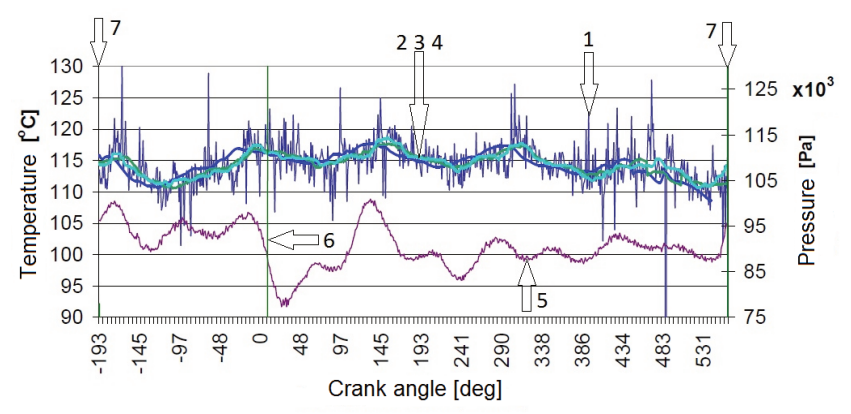

Fig. 5. Temperature change curves recorded in the exhaust channel of the Farymann D10 diesel engine with a type K thermocouple (grounded) during one of the work cycles filtered in Matlab; 1 - temperature recorded with a grounded thermocouple, 2 - temperature curve after the Savitzki and Golay filter, 3 - temperature curve after the median filter, 4 - temperature curve after the envelope filter 5 - pressure in the exhaust channel, $6-$ exhaust valve closing signal, 7 - exhaust valve opening signal

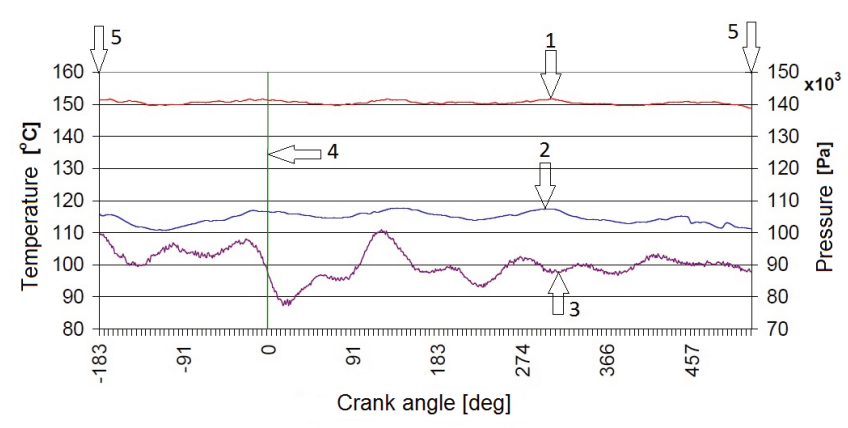

Fig. 6. Curves and changes of temperatures recorded with the two type K thermocouples during a single work cycle after mathematical processing in Matlab (envelope); 1 - temperature recorded with the exposed thermocouple after mathematical processing, 2- temperature recorded with the watercooled thermocouple after mathematical processing, 3 - pressure in the exhaust channel, 4 - exhaust valve closing signal, 5 - exhaust valve opening signal

All the applied methods of signal mathematical processing allowed an obtainment of curves of similar parameters (Fig. 4 and 5). The signal obtained after filtering is free from distortions resulting from the influence of noise caused by external factors (Fig. 6), which allows a more detailed interpretation of the obtained results. Therefore, a significant usefulness can be observed of the signal Matlab filtering method.

Two important problems remain for further considerations. First, one can see a significant difference in the readings of the thermocouples during the tests. The influence of the water-cooling (along with the heating of the channel walls) of the thermocouples on their readings needs to be determined. Another problem that needs attention is the shift of the temperature amplitude against the pressure amplitude, which results from the inertia of the thermocouple. It is, thus, necessary to determine the method of obtaining of the actual exhaust temperature, free from errors related to phase delay and amplitude distortion [17] of the recorded signal against the actual curve. 


\section{Conclusions}

After the preliminary investigations, it is expected that the fast-varying exhaust temperature may lead to the obtainment of diagnostic information related to the technical condition of the engine and the injection system. In order to develop a diagnostic method based on this parameter, one should allow for the requirement of high measurement accuracy, technology and ergonomics. The costs of purchase and implementation of the precise measurement equipment also need to be considered. One should mind the minimization of external factors. An equally important aspect is the selection of a proper method of mathematic processing of signals recorded during laboratory tests, including the determination of the time constant.
The proposed method of mathematical processing of a fast-varying diesel exhaust temperature signal consists in averaging of the signal with filters in the Matlab environment. In the next step one should consider developing a method of determination of the actual curve of the exhaust temperature change. In order to fully evaluate the usefulness of the developed method it will be necessary to carry out engine laboratory tests for different load conditions and apply the proposed method of signal correction for a wider group of measurement data. If, after this stage, the method is deemed useful, it may be used in further research works for mathematical processing of signals used in parametrical diagnosing of all types of piston machines, which may even increase its usefulness.

\section{Bibliography}

[1] BROWN, C., KEE, R.J., IRWIN, G.W. et al. Identification applied to dual sensor transient temperature measurement. UKACC Int Control Conference. Manchester 2008.

[2] GANDER, W., HREBICEK, J., Solving problems in scientific computing using Maple and Matlab. Springer. Berlin 2004.

[3] GORRY, P.A. General least - squares smoothing and differentiation by the convolution (Savitzky-Golay) method. Analytical Chemistry. 1990, 62(6), 570-573.

[4] JAREMKIEWICZ, M. Odwrotne zagadnienia wymiany ciepła, występujące $\mathrm{w}$ pomiarach nieustalonej temperatury płynów. Rozprawa doktorska. Wydawnictwo Politechniki Krakowskiej, Kraków 2011.

[5] JAREMKIEWICZ, M., TALER, J., Inverse determination of transient fluid temperature in pipelines. Journal of Power Technologies. 2016, 96(6), 385-389.

[6] KORCZEWSKI, Z. Exhaust gas temperature measurements in diagnostics of turbocharged marine internal combustion engines. Part I. Standard Measurements. Polish Maritime Research.2015, 22/1(85), 47-54.

[7] KORCZEWSKI, Z. Exhaust gas temperature measurements in diagnostics of turbocharged marine internal combustion engines. Part II. Dynamic Measurements. Polish Maritime Research. 23/1(89), 68-76.

[8] KORCZEWSKI, Z., Diagnostyka eksploatacyjna okrętowych silników spalinowych - tłokowych i turbinowych. Wybrane zagadnienia. Wydawnictwo Politechniki Gdańskiej. Gdańsk 2017.

[9] KORCZEWSKI, Z. The method of energy-efficiency investigations of the newly produced marine fuels through the application of a diesel engine. Materiały Konferencji MAPE, Explo-Ship 2018. Zawiercie.

[10] KORCZEWSKI, Z., PUZDROWSKA, P. Analytical method of determining dynamic properties of thermocouples used in measurements of quick - changing temperatures of exhaust gases in marine diesel engines. Combustion Engines. 2015, 162(3), 300-306.

[11] KORCZEWSKI, Z., ZACHAREWICZ, M. Alternative diagnostic method applied on marine diesel engines having limited monitoring susceptibility. Transactions of the Institute of Measurement and Control. 2012, 34(8), 937-946.

[12] KORCZEWSKI, Z., ZACHAREWICZ, M. Diagnostyka symulacyjna układu turbodoładowania okrętowego tłokowego silnika spalinowego. Zeszyty naukowe Akademii Marynarki Wojennej. 2007, 2(169).

[13] LUO, J., YING, K., BAI, J. Savitzky-Golay smoothing and differention filter for even number data. Signal Processing. 2005, 85(7), 1429-1434.

[14] MARSZAŁKOWSKI, K., PUZDROWSKA, P. A laboratory stand for the analysis of dynamic properties of thermocouples. Journal of Polish CIMEEAC. 2015, 10(1), 111-120.

[15] OLCZYK, A. Koncepcja pomiaru szybkozmiennej temperatury gazu z uwzględnieniem dynamicznej składowej temperatury. Pomiary Automatyka Kontrola. 2007, 53 Bis/9, 576579.

[16] PRATAP, R. Matlab dla naukowców i inżynierów. Państwowe Wydawnictwo Naukowe. Warszawa 2015.

[17] PUZDROWSKA, P. Determining the time constant using two methods and defining the thermocouple response to sine excitation of gas temperature. Journal of Polish CIMEEAC. 2016, 11(1), 157-167.

[18] SAVITZKY, A., GOLAY, M. J. E. Smoothing and differentiation of data by simplified least squares procedures. Analytical Chemistry. Illinois 1964.

[19] ZACHAREWICZ, M. Metoda diagnozowania przestrzeni roboczych silnika okrętowego na podstawie parametrów procesów gazodynamicznych w kanale zasilającym turbosprężarkę. Rozprawa doktorska. AMW, Gdynia 2009.
Patrycja Puzdrowska, MEng. - Faculty of Ocean Engineering \& Ship Technology, Gdansk University of Technology.

e-mail:patpuzdr@pg.edu.pl

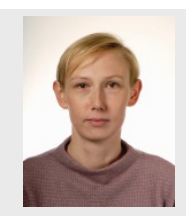

